Volume 5

$11-4-2014$

\title{
Blah, Blah, Blah: Making Sense of Nonsense in Irish Vocal Music
}

Catherine E. Mullins

Covenant College, catherineelaine@comcast.net

Follow this and additional works at: https://digitalcommons.cedarville.edu/musicalofferings

Part of the Musicology Commons

DigitalCommons@Cedarville provides a publication platform for fully open access journals, which means that all articles are available on the Internet to all users immediately upon publication. However, the opinions and sentiments expressed by the authors of articles published in our journals do not necessarily indicate the endorsement or reflect the views of DigitalCommons@Cedarville, the Centennial Library, or Cedarville University and its employees. The authors are solely responsible for the content of their work. Please address questions to dc@cedarville.edu.

\section{Recommended Citation}

Mullins, Catherine E. (2014) "Blah, Blah, Blah: Making Sense of Nonsense in Irish Vocal Music," Musical Offerings: Vol. 5 : No. 2 , Article 2.

DOI: 10.15385/jmo.2014.5.2.2

Available at: https://digitalcommons.cedarville.edu/musicalofferings/vol5/iss2/2 


\section{Blah, Blah, Blah: Making Sense of Nonsense in Irish Vocal Music}

\section{Document Type}

Article

\section{Abstract}

This paper seeks to provide a foundation for understanding lilting, a traditional type of vocal music found in Ireland that involves improvising non-lexical vocables to dance tunes, in order to help preserve this genre in its traditional form as well as encourage its transformation and incorporation into modern music. Through a case study, this research paper demonstrates certain features and patterns that may characterize traditional lilting. A recording of Seamus Fay's performance of the traditional folk jig, "Humours of Ballyloughlin," has been transcribed for analysis and examined for possible relationships of vocables or vowels to music and vocables to other vocables. Characteristics suggested by the transcription include the importance of [d], the extent of the vocable vocabulary used throughout the piece, the typical arrangement of vocables in relation to one another, and the connection between vocables to metric accents and vowels to agogic accents.

\section{Keywords}

Lilting, vocables, Irish, nonsense, dance, traditional music, vocal music

\section{Creative Commons License}

\section{(c) (1) $9 \odot$}

This work is licensed under a Creative Commons Attribution-Noncommercial-No Derivative Works 4.0 License. 


\title{
Blah, Blah, Blah:
}

\section{Making Sense of Nonsense in Irish Vocal Music}

\author{
Catherine Mullins \\ Covenant College
}

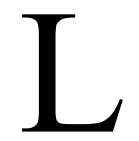

ilting is a traditional type of vocal music found in Ireland and Scotland that involves improvising non-lexical vocables to dance tunes. ${ }^{1}$ Although still performed today, this Celtic scat singing, as it may be deemed, has received insufficient attention by researchers. ${ }^{2}$ Perhaps the reason for this oversight is due to the difficulties inherent in analyzing a genre that is orally transmitted and involves nonsensical, improvisational lyrics. Indeed, in vocal music with translatable texts, there tends to be a special connection between words and music that makes such works especially amenable to analysis; the music clarifies and strengthens the meaning and emotions of the text through melody, harmony, and other aspects of musical style, and the text is likewise often crucial to fully understanding and analyzing the music to which it is set. Nevertheless, despite the lack of meaning in lilting, an intimate relationship between lyrics and music may still exist in this genre, only on rather more technical terms. Instead of relating text to such aspects of music as harmony, nonsense lyrics require relating phonetic sounds to such aspects of music as metric accent. Therefore, the purpose of this research paper is not only to examine the vocables used in lilting, but also to explore the relationship of vocables to melodic contour and musical accents in order to demonstrate, through a case study, which features and patterns may characterize traditional lilting.

\footnotetext{
${ }^{1}$ Francis Collinson and Peter Cooke, "Lilt," Grove Music Online, (Oxford University Press, 2013.) "Lilting" is the Irish name for the practice; in Scotland it is termed "diddling." My paper focuses on lilting in its Irish form.

${ }^{2}$ Similarity between lilting and scat singing is implied in Heather Sparling, "'Music is Language and Language is Music': Language Attitudes and Musical Choices in Cape Breton, Nova Scotia," in Ethnologies 25, no. 2 (2003), 159.
}

Musical Offerings, vol. 5, no. 2, pp. 87-117. ISSN 2330-8206 (print); ISSN 2167-3799 (online);

(C) 2014, Catherine Mullins, licensed under CC BY-NC-ND (http://creativecommons.org/licenses/by-nc-nd/3.0/) 


\section{Motivation}

A study of the relationship of vocables to music and vocables to other vocables provides a foundation for understanding lilting that can help preserve it in its traditional form as well as encourage its transformation and incorporation into modern music. The possibilities of incorporating aspects of lilting into modern compositions and performances are enormous, but only if the genre is known and understood. For composers who have not grown up with exposure to lilting, this analysis may assist in gaining such an understanding. ${ }^{3}$

A foundation for analyzing lilting is found in the works of David Hughes, whose research on the use of non-lexical vocables in music from Japan and Korea gives precedence for a technical approach to relating "nonsense" vocables to musical features. In his article, "No Nonsense: The Logic and Power of Acoustic-Iconic Mnemonic Systems," Hughes attempts to demonstrate that "certain acousticphonetic features of vowels and consonants lead to similar systems of mnemonics existing independently in widely separated cultures." 4 Because "certain phonetic features of the syllables - both vowels and consonants - are in an iconic relation to the musical sounds they represent," he believes in a certain universality of systems of nonsense vocables, enabling musicians from broadly divergent cultures to understand each other's systems. ${ }^{5}$ If such qualities may indeed unite music systems from such linguistically different countries as Japan and Uganda, as Hughes suggests, it can be expected that they ought to be found common to Celtic music as well. ${ }^{6}$

In his analysis of the Korean oral mnemonic system, yukpo, Hughes notes a correlation between relative pitch (as determined by relative melodic movement) and vowel timbre - a phenomenon consistent with his observations of oral mnemonic systems in Japan, Indonesia, India,

\footnotetext{
${ }^{3}$ For an example of a successful transformation of lilting into a modern composition, see Afro-Celtic Diddle by Michael Coolen. In this case, the composer's knowledge came solely from childhood exposure to lilting.

${ }^{4}$ David W. Hughes, "No Nonsense: The Logic and Power of Acoustic-Iconic Mnemonic Systems," in British Journal of Ethnomusicology 9, no. 2 (2000), 93.

${ }^{5}$ Hughes, "No Nonsense," 93-94.

${ }^{6}$ Ibid, 94.
} 
and Scotland. ${ }^{7}$ In order to explain this common pattern, he proposes that it results from the "Intrinsic Pitch" of the vowels. Intrinsic Pitch of vowels corresponds to the frequency of the second formant resonating chamber, which is the oral cavity. Because different vowels demand the mouth to take on different shapes, the frequency of this chamber changes accordingly. ${ }^{8}$ While Hughes does not consider the principle of Intrinsic Pitch to be particularly determinative in lilting, he suggests that other intrinsic qualities of vowels might be reflected in the vocables:

In lilting or 'diddling'...Intrinsic Intensity and Duration play an important role. In a phrase in a $6 / 8$ jig...the relatively strong backbeat tends to be represented by syllables with "heavier" vowels, such as "ah," "um" or " $i$ " (here pronounced [ay]), whereas the weaker or shorter notes tend to use the sounds [I] or $[\mathrm{i}] .^{9}$

If this observation is true, there should be a relationship between vowels and metric and agogic accents. ${ }^{10}$

\section{Methods}

For the purpose of this research paper, the recordings of Seamus Fay, born 1932, an accomplished lilter from Ireland whose skills were shaped by his mother and grandmother, are given primary consideration. ${ }^{11}$ In particular, his performance of the traditional folk jig, "Humours of Ballyloughlin," has been transcribed for analysis.

\footnotetext{
${ }^{7}$ David Hughes, "Oral Mnemonics in Korean Music: Data, Interpretation, and a Musicological Application," in Bulletin of the School of Oriental and African Studies, University of London 54, no. 2 (1991), 308, 310-311, 320.

${ }^{8}$ Hughes, "No Nonsense," 98-99.

${ }^{9}$ Ibid, 112.

${ }^{10}$ The strength of a metric accent is determined according to where a note falls within a measure. A note that falls on the first beat of a measure will have the strongest metric accent. Notes that fall on subsequent beats are somewhat weaker, while those that fall between beats are weaker still. The strength of an agogic accent is determined by the relative duration of a pitch. A note with a strong agogic accent is held longer than other notes.

${ }^{11}$ Yasmin Maassarani, "Cavan Lilter, Seamus Fay's Birthday Concert," Cavan Living, December 19, 2012,
} 
In order to understand the nature and limitations of the transcription, the approaches used in its creation must be discussed before its analysis. The task of transcription bears with it a number of complications, both in regard to notating music and indicating vocable pronunciation. The amount of specific performance detail that may be considered for notation is immense. According to George List of Indiana University, "No method of transcription yet devised, whether accomplished by means of the human ear or by electronic apparatus, mirrors the musical event with exactitude."12 Furthermore, Béla Bartók pointed out that folk music is full of variation because it does not bind performers to notated music. ${ }^{13}$ While my transcription attempts to recognize some level of variation within the folk tune performed, it does not attempt to incorporate "all elements of the music and its performance," as would be characteristic of an analytical transcription. ${ }^{14}$ Rather, it is a simple melodic transcription, accomplished by means of the human ear. Notation of artistic nuance is not considered in it because it is unnecessary for understanding the relationship of vocables to such aspects of music as metric accent and relative pitch.

In regard to transcription of vocables, several methods are possible. Orthographic transcription, the least precise approach, is limited to the letters of the alphabet. While this may be the easiest transcription to create because it deals with familiar symbols, it is insufficient because it fails to adequately record pronunciation. According to Leslie De'Ath, "in hybrid languages that have undergone significant sound pattern changes over the centuries, such as English, there is a frequent lack of correspondence between spelling and pronunciation." ${ }^{15}$ For example,

http://www.cavanliving.ie/index.php/2012/12/19/lilter-seamus-fays-birthdayconcert-cavan/.

${ }^{12}$ George List, "The Musical Significance of Transcription: (Comments on Hood, 'Musical Significance')," in Ethnomusicology 7, no. 3, (Sep., 1963), 194.

${ }^{13}$ Béla Bartók and Albert Bates Lord, Serbo-Croatian Folk Songs: Texts and Transcriptions of Seventy-Five Folk Songs from the Milman Parry Collection and a Morphology of Serbo-Croatian Folk Melodies. (New York: Columbia University Press, 1951), 19-20.

${ }^{14}$ Avigdor Herzog, "Transcription and Transnotation in Ethnomusicology," in Journal of the International Folk Music Council 16 (1964), 100.

${ }^{15}$ Leslie De'Athe, "Phonemics and Lyric Diction," in Journal of Singing: The Official Journal Of the National Association Of Teachers Of Singing 62, no. 5 (May-June 2006), 552. 
one letter may have multiple pronunciations and one pronunciation may have multiple spellings. ${ }^{16}$ Due to the ambiguity inherent in orthographic transcription, an alternative system is needed. Therefore, for the purpose of this study, a broad phonetic transcription has been applied to the lilting vocables.

\section{Results and Discussion}

The transcription of Fay's performance of the jig "Humours of Ballyloughlin" demonstrates several patterns. First, the variety of consonants, simple vowels (monothongs), and complex vowels (dipthongs) used was very limited (see Figure 1). ${ }^{17}$

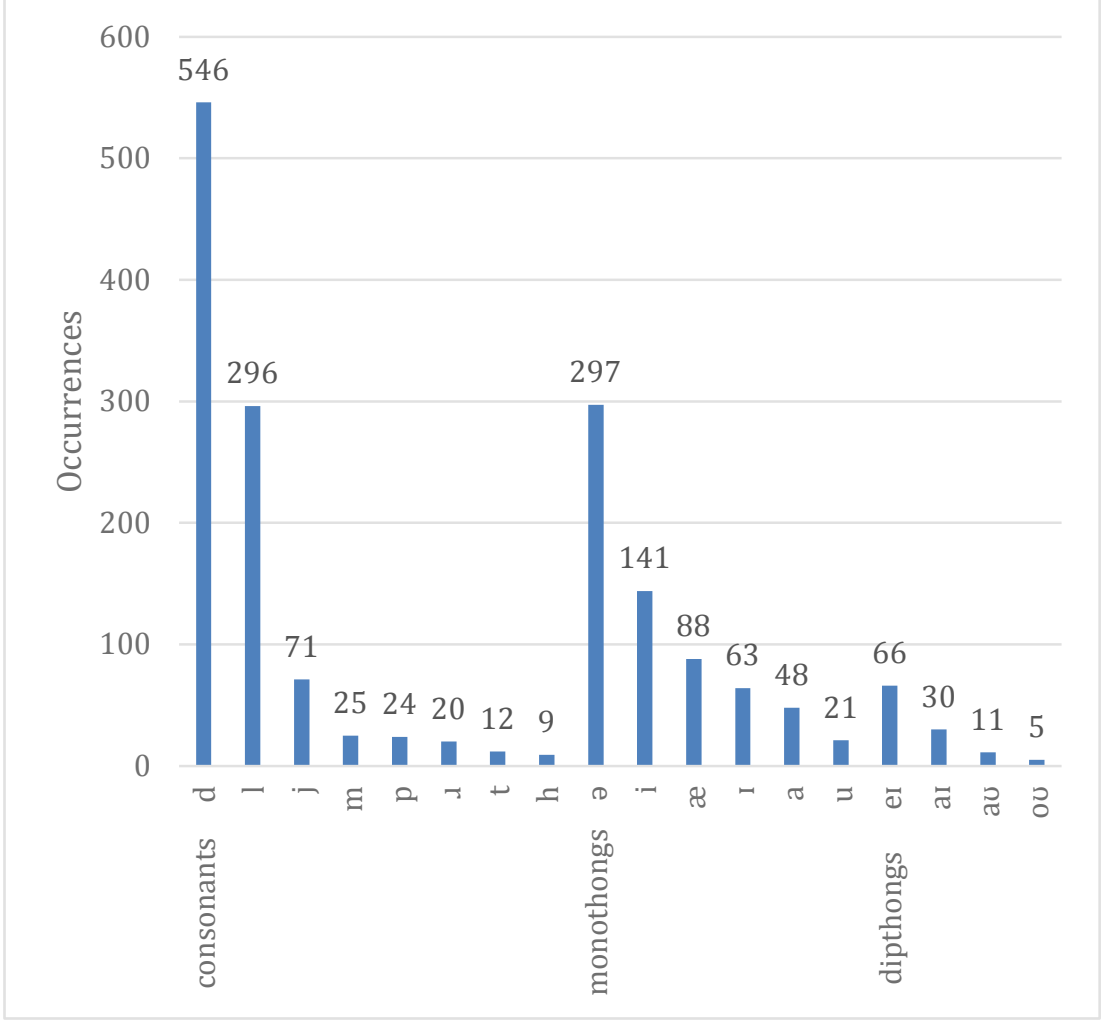

Figure 1: Consonants and Vowels in "Humours of Ballyloughlin"

\footnotetext{
${ }^{16}$ Vedrana Mihalicek and Christin Wilson, Language Files: Materials for an Introduction to Language and Linguistics (Columbus: Ohio State University Press, 2011), 39-40.

${ }^{17}$ A chart can be found in Appendix A to assist in understanding the International Phonetic Alphabet (IPA) symbols used in the transcription.
} 
It is significant that [d] occurs much more frequently than any other consonant or vowel. This is one of the 'stop' consonants that, according to Hughes, "generally mark the sharp attack of a plucked string or struck membranophone or idiophone." ${ }^{18}$ Given the fact that lilting involves Celtic dance tunes in which rhythm is of great importance, the harshness of this consonant may be interpreted as reflecting the beat of the Bodhran (Celtic drum) or perhaps even the grace note cuts of the bagpipe.

This transcription also indicates that the vocabulary of vocables Fay used in lilting this particular jig was fairly limited. A list of all vocables used in "Humours of Ballyloughlin," along with the number of times they appeared in the performance, can be found in Table 1. While most vocables were repeated a number of times, a few showed up only once or twice. However, these did not necessarily stand out starkly. Some of these vocables may be variations of other, more commonly occurring vocables. For example, the vocables [jom] and [ləm] appear to be variations of $[\mathrm{d} \partial \mathrm{m}]$. These vocables not only sound similar, but also appear in the same metric positions (see Table 1) and are the only vocables that precede a vocable starting with [p] (see Appendix C).

The transcription of "Humours of Ballyloughlin" indicates a melodic form of $\|: A:\|: B:\|: C:\|: D:\|: A:\|: B:\|: C:\|: D: \|$. While repetitions of the melody are accomplished with negligible levels of deviation, there is always some amount of variation in the corresponding vocables. Nevertheless, despite the fact that the lilter may theoretically sing any vocable he or she pleases at any point in the tune, Fay establishes a general pattern of vocables for each portion of music, and he is remarkably consistent. When a section of melody is repeated, the corresponding vocables are similar. The excerpt of the transcription in Figure 2 presents an example of this pattern. In order to facilitate comparison, sections of similar melodic material have been organized vertically in the transcription. ${ }^{19}$ The first section of melody appears in the top section; its immediate repeat is found in the second system. When these nearly identical sections of melody are compared, it becomes apparent that the order and type of vocables used in each version are identical in all but eight instances. Furthermore, in those instances in which the vocables of the repeated melody are not identical to the original, they are frequently similar. For example, in Figure 2 the

\footnotetext{
${ }^{18}$ Hughes, "No Nonsense," 97.

${ }^{19}$ See Appendix B.
} 
initial consonants of the second vocable in $\mathrm{A} 1$ and $\mathrm{A} 2$ are different, but the vowels are the same. Additional instances of this may be found in Appendix B, which features the complete transcription of Fay's "Humours of Ballyloughlin." As in the example below, sections of repeated melodic material have been vertically oriented.

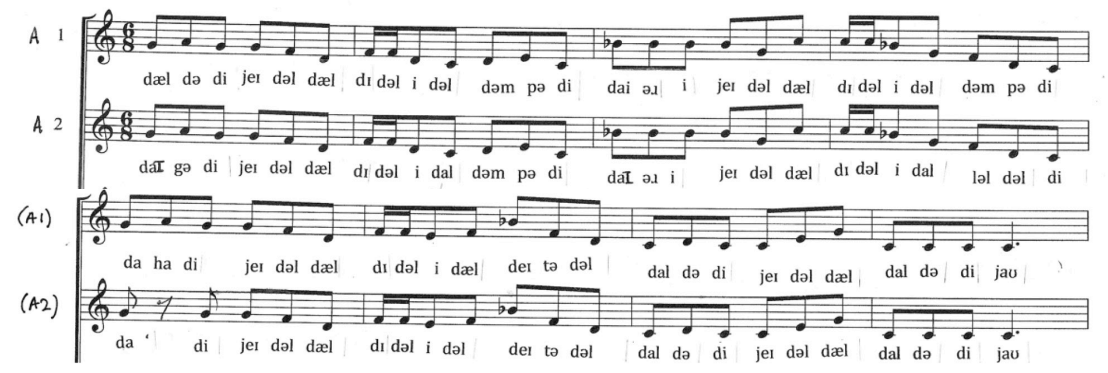

Figure 2: "Humours of Ballyloughlin"-Transcription of First Sections of Melody

The fact that this tune was intended for dance may provide an explanation for the similarities found in vocables in repeated sections of melody. Because of the regular, repetitious nature of dancing, there must be some amount of consistency and repetition in dance music. This is apparently reflected not only in the melodies lilted, but also in the vocables.

Similar vocable arrangement can also be found, to some extent, across sections of dissimilar melodic material. By grouping together vocables falling within a single beat, one finds a number of groups that show up throughout the piece. Certain vocable groups, such as [dI-dəl-i-dəl], appear in each of the four sections of melody. ${ }^{20}$ The chart in Appendix $\mathrm{C}$, which contains observations such as which vocables usually precede or follow a given vocable, further demonstrates a common arrangement of vocables throughout the jig. These similar vocable patterns unify the distinct melodic sections.

\footnotetext{
${ }^{20}$ See Appendix D for a list of the vocable groups observed in "Humours of Ballyloughlin." The groups have been organized alphabetically in order to show that, despite the fact that there are many different vocable groups, many of them are very similar.
} 
Although perhaps less remarkable, some patterns may also be observed in the order of vowels in "Humours of Ballyloughlin." Many vowels never occur consecutively. For example, a vocable containing [a] never precedes a vocable containing [ai]. On the other hand, some vowels frequently follow each other. Such is the case with [ov], which is all but once preceded by [æ]. The result is yet more patterns that unify the jig as a whole. ${ }^{21}$

The transcription also indicates some level of correspondence between vocables and metric or agogic accents. In order to visualize the relative metric strength of each vocable, their "average strength" has been calculated (see Table 1). For each time the vocable was observed on the down beat, second beat, or off beat, it would receive a score of 1,0 , or 1 , respectively. The total score of the vocable was then divided by its total number of occurrences to determine its "average strength." Therefore, scores closer to 1 indicate a generally strong metric position, while scores approaching -1 indicate a generally weak metric position. Vocables are organized in terms of descending order of calculated strength. Under the columns labeled "Strong," "Medium," and "Weak," the first number indicates how many times a particular vocable appears in one of those metric positions, while the number within parentheses indicates what percentage of the vocable's occurrences fall in each position.

\footnotetext{
${ }^{21}$ Although created for a different purpose, the chart in Appendix E details
} which particular vowels precede other vowels, and how frequently. 
Table 1: Vocables and Metric Accent

\begin{tabular}{|c|c|c|c|c|c|}
\hline Vocables & Occurrences & $\begin{array}{l}\text { Strong } \\
\text { (first } \\
\text { beat) }\end{array}$ & $\begin{array}{l}\text { Medium } \\
\text { (second } \\
\text { beat) }\end{array}$ & $\begin{array}{l}\text { Weak } \\
\text { (between } \\
\text { beats) }\end{array}$ & Strength \\
\hline ja & 1 & $1(100 \%)$ & $0(0 \%)$ & $0(0 \%)$ & 1 \\
\hline jaI & 1 & $1(100 \%)$ & $0(0 \%)$ & $0(0 \%)$ & 1 \\
\hline daI & 29 & $28(97 \%)$ & $1(3 \%)$ & $0(0 \%)$ & .97 \\
\hline $\mathrm{da}$ & 24 & $23(96 \%)$ & $1(4 \%)$ & $0(0 \%)$ & .96 \\
\hline $\mathrm{dI}_{\mathrm{I}}$ & 53 & $32(60 \%)$ & $21(40 \%)$ & $0(0 \%)$ & .60 \\
\hline ləl & 11 & $4(36 \%)$ & $7(64 \%)$ & $0(0 \%)$ & .36 \\
\hline deI & 15 & $4(27 \%)$ & $11(73 \%)$ & $0(0 \%)$ & .27 \\
\hline dəm & 22 & $5(23 \%)$ & $17(77 \%)$ & $0(0 \%)$ & .23 \\
\hline jeI & 44 & $9(20 \%)$ & $35(80 \%)$ & $0(0 \%)$ & .2 \\
\hline jav & 9 & $0(0 \%)$ & $9(100 \%)$ & $0(0 \%)$ & 0 \\
\hline leI & 7 & $0(0 \%)$ & $7(100 \%)$ & $0(0 \%)$ & 0 \\
\hline dov & 5 & $0(0 \%)$ & $5(100 \%)$ & $0(0 \%)$ & 0 \\
\hline dav & 2 & $0(0 \%)$ & $2(100 \%)$ & $0(0 \%)$ & 0 \\
\hline ləm & 2 & $0(0 \%)$ & $2(100 \%)$ & $0(0 \%)$ & 0 \\
\hline jəm & 1 & $0(0 \%)$ & $1(100 \%)$ & $0(0 \%)$ & 0 \\
\hline lil & 1 & $0(0 \%)$ & $1(100 \%)$ & $0(0 \%)$ & 0 \\
\hline dal & 11 & $5(45 \%)$ & $0(0 \%)$ & $6(55 \%)$ & $\begin{array}{l}.09 \\
\end{array}$ \\
\hline dæl & 88 & $12(14 \%)$ & $0(0 \%)$ & $76(86 \%)$ & -.73 \\
\hline Ii & 6 & $0(0 \%)$ & $1(17 \%)$ & $5(83 \%)$ & -.83 \\
\hline do & 53 & $0(0 \%)$ & $5(9 \%)$ & $48(91 \%)$ & -.91 \\
\hline də1* & 151 & $4(3 \%)$ & $2(1 \%)$ & $145(96 \%)$ & -.93 \\
\hline di & 74 & $0(0 \%)$ & $0(0 \%)$ & $74(100 \%)$ & -1 \\
\hline $\mathrm{i}$ & 60 & $0(0 \%)$ & $0(0 \%)$ & $60(100 \%)$ & -1 \\
\hline $\mathrm{du}$ & 16 & $0(0 \%)$ & $0(0 \%)$ & $16(100 \%)$ & -1 \\
\hline jə & 14 & $0(0 \%)$ & $0(0 \%)$ & $14(100 \%)$ & -1 \\
\hline$\partial \mathrm{I}^{* * *}$ & 13 & $0(0 \%)$ & $0(0 \%)$ & $13(100 \%)$ & -1 \\
\hline to & 11 & $0(0 \%)$ & $0(0 \%)$ & $11(100 \%)$ & -1 \\
\hline pol & 8 & $0(0 \%)$ & $0(0 \%)$ & $8(100 \%)$ & -1 \\
\hline ha & 9 & $0(0 \%)$ & $0(0 \%)$ & $9(100 \%)$ & -1 \\
\hline pI & 9 & $0(0 \%)$ & $0(0 \%)$ & $9(100 \%)$ & -1 \\
\hline po & 7 & $0(0 \%)$ & $0(0 \%)$ & $7(100 \%)$ & -1 \\
\hline dul & 5 & $0(0 \%)$ & $0(0 \%)$ & $5(100 \%)$ & -1 \\
\hline $\mathrm{a}$ & 3 & $0(0 \%)$ & $0(0 \%)$ & $3(100 \%)$ & -1 \\
\hline$\partial$ & 2 & $0(0 \%)$ & $0(0 \%)$ & $2(100 \%)$ & -1 \\
\hline gə & 2 & $0(0 \%)$ & $0(0 \%)$ & $2(100 \%)$ & -1 \\
\hline Iว & 1 & $0(0 \%)$ & $0(0 \%)$ & $1(100 \%)$ & -1 \\
\hline ti & 1 & $0(0 \%)$ & $0(0 \%)$ & $1(100 \%)$ & -1 \\
\hline
\end{tabular}

* Sometimes shortened to syllabic consonant: [dl]

** Sometimes shortened to syllabic consonant: [r] 
For the most part, each vocable has a characteristic metric position in which it appears. Most strikingly, only five vocables appear both on a beat and between beats. Of those, only the most frequently occurring vocable, [dəl], can be found on the first beat, second beat, and between beats. $^{22}$

Table 2 explores to what extent this pattern may be ascribed to the vowel within the vocable. The chart demonstrates a relationship between vowel and metric accent, though it is not nearly as consistent as the relationship between vocables and metric accent. Unlike the vocables, half of the vowels appear both on a beat and between beats. Nevertheless, there is a remarkably regular relationship between metric accent and the diphthongs (complex vowels). All vocables involving a diphthong always land on a beat.

Table 2: Vowels and Metric Accent

\begin{tabular}{|c|c|c|c|c|c|}
\hline Vowels & Occurrences & $\begin{array}{l}\text { Strong } \\
\text { (down- } \\
\text { beat) }\end{array}$ & $\begin{array}{l}\text { Medium } \\
\text { (second } \\
\text { beat) }\end{array}$ & $\begin{array}{l}\text { Weak (not } \\
\text { on beat) }\end{array}$ & $\begin{array}{l}\text { Average } \\
\text { strength }\end{array}$ \\
\hline aI & 30 & $29(97 \%)$ & $1(3 \%)$ & $0(0 \%)$ & .97 \\
\hline I & 63 & $32(51 \%)$ & $22(35 \%)$ & $9(14 \%)$ & .37 \\
\hline $\mathrm{a}$ & 48 & $29(60 \%)$ & $1(2 \%)$ & $18(38 \%)$ & .23 \\
\hline ei & 66 & $13(20 \%)$ & $53(80 \%)$ & $0(0 \%)$ & .17 \\
\hline av & 11 & $0(0 \%)$ & $11(100 \%)$ & $0(0 \%)$ & 0 \\
\hline ov & 5 & $0(0 \%)$ & $5(100 \%)$ & $0(0 \%)$ & 0 \\
\hline dæl & 88 & $12(14 \%)$ & $0(0 \%)$ & $76(86 \%)$ & -.73 \\
\hline$\partial$ & 297 & $13(4 \%)$ & $34(11 \%)$ & $250(84 \%)$ & -.80 \\
\hline $\mathrm{i}$ & 141 & $0(0 \%)$ & $2(1 \%)$ & $139(99 \%)$ & -.99 \\
\hline $\mathrm{u}$ & 21 & $0(0 \%)$ & $0(0 \%)$ & $21(100 \%)$ & -1 \\
\hline
\end{tabular}

While agogic accents occur very infrequently in the jig, a relationship between these accents and vocables is nevertheless apparent. Most of the agogic accents appear at the end of melodic sections, where only three different vocables are ever heard-[dov], [dav], and [jav]. Fay seems to have selected these three to be his special terminating vocables, for they can be found nowhere else in the jig. In contrast,

${ }^{22}$ Further connection in placement can be seen in Appendix C, which observes where the weak vocables usually fall in terms of specific location of the off beat. There is consistency here as well. 
agogically accented vocables ending in [a] or [eI] fall within sections of melody.

Table 3: Vocables and Agogic Accent

\begin{tabular}{|l|l|l|l|}
\hline \multicolumn{2}{|l|}{ quarter note } & dotted quarter \\
\cline { 1 - 2 } vocable & occurrences & vocable & occurrences \\
\hline da & 3 & jav & 9 \\
\hline dou & 2 & dov & 3 \\
\hline deI & 1 & dav & 2 \\
\cline { 1 - 2 } ha & 1 & \multicolumn{2}{|l}{} \\
\cline { 1 - 2 } ja & 1 & &
\end{tabular}

An additional chart is unnecessary to illustrate the relationship between vowels and agogic accents, as Fay selects only one monothong and three diphthongs to fill these positions. There is a clear connection between the diphthongs [av] and [ov] and this type of accent, for they are never used in agogically unaccented positions. The use of [a] in agogically-accented positions seems to reflect the influence of Intrinsic Duration, for, as Hughes noted, "[a] has the greatest intrinsic duration and intensity." 23

It is also remarkable that the vocables [dI] and [dəl] are the only ones that ever appear with sixteenth notes, which represent the shortest value of note duration within the piece. The shortness of [dI] is consistent with Hughes's observations of a lilted jig, in which he stated that "shorter notes tend to use the [sound] [I]." ${ }^{24}$ This supports his hypothesis that the Intrinsic Duration of vowels affects the vocables sung in lilting.

While so far we have considered the relationship of vocables to accent, at this point we will look at the relationship of vowels to pitch. In order to study this, the number of times each particular vowel sung was preceded by a higher pitch, the same pitch, or a lower pitch has been determined. ${ }^{25}$ Figure 3 shows, according to percentage, how each vowel was typically approached. As [I] is generally preceded by a lower pitch, it therefore has a high relative pitch. On the other hand, [i] and $[\mathrm{u}]$ are generally preceded by higher pitches, and their relative

\footnotetext{
${ }^{23}$ Hughes, "Oral Mnemonics in Korean Music," 312.

${ }^{24}$ Hughes, "No Nonsense," 112.

${ }^{25}$ A complete chart detailing how each vowel was approached by other vowels can be found in Appendix E.
} 
pitch is therefore low. [ə] falls somewhere in between, as it is preceded with similar frequency by higher, lower, and identical pitches. While the low relative pitch of [i], a vowel of high Intrinsic Pitch, supports Hughes's "impression...that Intrinsic Pitch plays little or no role in lilting," the low relative pitch of $[\mathrm{u}]$, a vowel of low Intrinsic Pitch, suggests that there may yet be some amount of relationship between the relative pitch of vowels and Intrinsic Pitch in lilting. ${ }^{26}$ However, further transcription and research of lilting is necessary to establish whether or not this relationship plays a role in vowel choice.

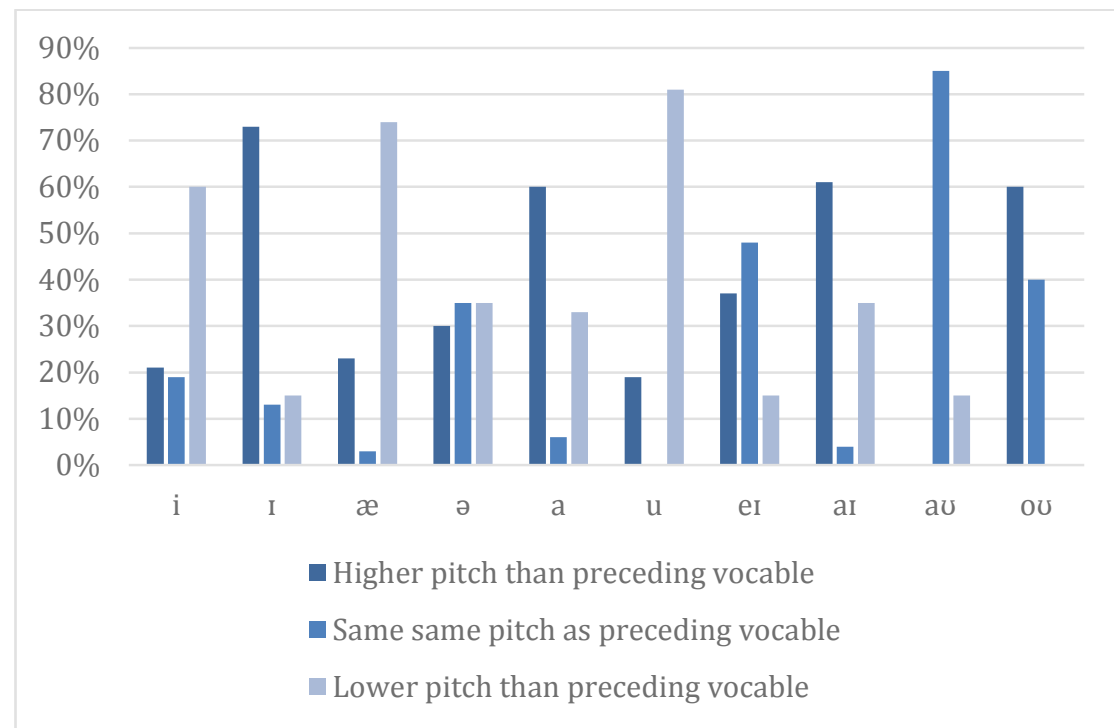

Figure 3: Vowel and Melodic Motion

\section{Comparison with Other Lilting Performances}

The patterns observed in "Humours of Ballyloughlin" are not unique to that particular jig. While relationships between vowels and relative pitch are difficult to accomplish without creating additional transcriptions, a preliminary, aural comparison is sufficient to demonstrate that many of the characteristics outlined above can be heard in Fay's other performances of jigs in his album, Cavan's Lilter. For example, there is a clear similarity in regard to the vowels and consonants used. In particular, the frequent use of [d] is common to all the jigs. Nevertheless, there may be an amount of variation in terms of which consonants are chosen. In particular, [1] seems to occur more

${ }^{26}$ Hughes, "No Nonsense," 99, 112. 
frequently in "Woods of Old Limerick" than it does in some of the other jigs. This somewhat softens the sound of the lilting. Also, as in "Humours of Ballyloughlin," there is much repetition of vocables. As before, where melodic material is repeated, the corresponding vocables tend to be similar.

The most striking similarity between the jigs is the recurrence of certain vocable groups, for common groups observed within "Humours of Ballyloughlin" can also be heard in other jigs. ${ }^{27}$ For example, [jeI-dudæl], a vocable group that occurred over a half-dozen times in "Humours of Ballyloughlin" can be heard recurring a number of times in "Pat Burke's." ${ }^{8}$ At times, Fay's different lilted jigs sound like the same song set to different tunes. While the jigs may vary in their emphasis of particular groups, there nevertheless appears to be a common vocable vocabulary from which they are drawn. For example, the jig "Richard Dwyers" makes particularly frequent use of the vocable group [daI-əI-i]. This is a vocable group which, though perhaps less prominent, appeared a number of times within "Humours of Ballyloughlin."

The fact that the vocable groups are similar from jig to jig within Fay's performances helps make apparent the relationship between accent and vocable that is in these jigs. Since the first vocable in each group always falls on the beat while all those that follow do not, shared groupings of vocables from jig to jig mean that particular vocables are falling regularly on or off the beat. By way of explanation, in the vocable group [daI-əI-i], common to both "Humours of Ballyloughlin" and "Richard Dwyer's," the first vocable [dar] falls on the beat while [ə.] and [i] do not. This pattern is the case for all groups. Therefore, the fact that many of the same vocable groups can be found in multiple jigs suggests that the relationship between metric accent and vocables in these works is comparable.

There also appears to be a common correspondence amongst the jigs between agogic accent and vowel. In almost every case, any jig that featured a pause at the end of a section of melody also featured a vocable with the complex vowel [av] or [ou]. In a few cases, these

\footnotetext{
${ }^{27}$ Vocable groups include all vocables that fall within the same beat. See Appendix D for a list of groups found in "Humours of Ballyloughlin."

${ }^{28}$ Dashes are used as a convenience to separate vocables within the same group.
} 
complex vowels occurred in places within a section of melody. This contrasts with "Humours of Ballyloughlin," in which [av] and [ov] were only used in the termination of a section of melodic material. However, there remains consistency in the fact that these two particular complex vowels only occur in agogically-accented positions within Fay's lilted jigs. It is also notable that a few jigs, such as "Richard Dwyer's," feature other vocables such as [da] for the closing of melodic material.

The patterns found through the transcription of "Humours of Ballylouglin" are not only found in other lilted jigs by Fay, but can also be seen to some extent in other types of lilted dances. In order to illustrate this point, we will look specifically at recordings of Fay lilting reels, another type of fast Irish dance.

One of the first consistencies observed between Fay's jigs and reels is, once again, the constant use of [d]. In his reels, almost every vocable that lands on a beat starts with a [d], though an occasional [j] or [1] might appear at the beginning of metrically strong vocables.

There is also some contrast between the jigs and reels in terms of vowels. Most noticeably, [u] appears frequently in metrically accented vocables. In the jig transcription, this vowel never appears in vocables that land on a beat. This discrepancy would seem to contradict the idea that the relationship observed between metric accent and vowel or vocable in the jig transcription indicates a broader principle or pattern. However, two explanations present themselves for this observation. First, since the transcription of "Humours of Ballyloughlin" shows that some vocables of predominantly weak metric accent, such as [dəl], occasionally fall on beats, there is precedence for the idea that predominantly weak vocables may occasionally appear in other metric positions. Second, it may be that the vocable and metric accent relationship found in the jig transcription simply does not fully apply to the lilting practice for reels. Perhaps there is a different pattern applied when reels are lilted, or perhaps reels are simply less strict in regard to which vowels may fall on the beat.

Another remarkable characteristic of the vocables used in Fay's reels is the use of syllabic consonants, particularly [l], within vocables in weak 
metric positions. ${ }^{29}$ This creates a closed, less resonant sound that results in a greater contrast between the strong, metrically-accented vocables and the weak ones.

The connection between agogic accent and the complex vowels [or] and $[\mathrm{a} \sigma]$ remains remarkably consistent throughout both Fay's reels and jigs. However, the fast nature of the reel means that notes which would be agogically accented on an instrument are cut short by the need to breathe in lilting. Therefore, the duration of [ov] and [av] is significantly shortened.

The fact that jigs are always in compound meter and reels are always in simple renders it difficult to observe similarities in vocable groups between the two dances, for, in accordance with their respective meters, the first frequently features three vocables in a single beat, while the second only two. Nevertheless, the vocable groups found in Fay's reels often sound like abbreviated versions of the vocable groups found in his jigs. Instead of jig groupings such as [dæl-də-di] and [jeI-du-dæl], one hears groups such as [dæl-də] and [jeI-du].

\section{Broader Application and Further Research}

It is difficult to assess to what extent the characteristics of Fay's performances reflect those of the broader body of Irish lilting because there is a limited number of lilting recordings available for comparison. Two lilted reels by different artists appear on Fay's album, but these artists claimed to be influenced by Fay. ${ }^{30}$ Therefore, the similarities that exist amongst them may be ascribed to Fay's influence rather than to some broader lilting principle. ${ }^{31}$ Further research into Irish lilting with

${ }^{29}$ Syllabic consonants, which are voiced like vowels, do appear within the "Humours of Ballyloughlin," but as abbreviations of other vocables (and hence are not distinguished within my transcription).

${ }^{30}$ According to album description; "Seamus Fay: Cavan's Lilter," Celtic Grooves, accessed Dec. 5, 2013, http://celticgrooves.homestead.com/CG Fay Seamus.html.

${ }^{31}$ There are actually some interesting differences between Fay's lilting and the lilting examples of Aoif Murry and Catrione Cullivan featured on his album. Rather than $[\mathrm{ov}]$ or $[\mathrm{av}]$ for agogic accents and ends of melodic sections, Murry seems to prefer [dəm]. Furthermore, she does not limit herself to Fay's vocable vocabulary, but rather has a few of her own vocables that she uses with some frequency. By contrast, Cullivan's lilting vocabulary seems to be rather more limited than that of Fay or Murry. The syllabic consonant [1] seems to be used for almost every metrically unaccented vocable. The variety 
the intention of comparing the lilting of various artists would provide a better understanding of the "big picture" of lilting; this research project is an admittedly limited case study, intended as a model or starting point for further examination of the topic. Beyond Ireland, it would be interesting to compare lilting as it occurs in various countries, such as Scotland and the parts of Canada under strong Celtic influence.

A comparison may also be drawn between lilting and other forms of Celtic music involving nonsense syllables. In canntaireachd ("humming a tune"), found in Scotland, vocables are used to train bagpipers. ${ }^{32}$ The vocables indicate not only which pitches are to be played, but also which grace notes are to be performed. ${ }^{33}$ Also found in Scotland, the waulking-song bears some resemblance to canntaireachd. Originally used to keep time while women worked on woven fabrics, these songs feature refrains containing non-lexical vocables. ${ }^{34}$ As in canntaireachd, there appears to be a system to the nonsense, even though the vocables in waulking-songs cannot be considered a form of notation. ${ }^{35}$ Nevertheless, they do have "their own rules of construction; only certain consonants and vowels are used, and these only in selected combinations." ${ }^{36}$ Furthermore, "though the same refrain syllables recur throughout the labour songs, a sequence of syllables constituting a complete musical phrase is almost never duplicated in different songs." ${ }^{37}$ According to Francis Collinson, the pattern of long and short vowels used in the refrain vocables is directly related to the rhythm, such that "in print, if the long vowels of the waulking-song are properly indicated by accent marks, grave or acute, it is often possible to read roughly the rhythm of a refrain from the long and short vowels in this way without the musical notation." "Further research may involve looking for canntaireachd and waulking-song vocables in lilting or

in her performance is in the vocables she chooses to sing in the metrically strong positions. Furthermore, her lilting, unlike that of Murry and Fay, features occasional rolled r's,

${ }^{32}$ Kenneth Elliot, et al., "Scotland," in Grove Music Online, (Oxford University Press, 2013), 16.

${ }^{33}$ J. P. Grant 1925. "Canntaireachd: the Old Pipers' Notation for Pibroch Music," in Music and Letters 6, no. 1 (1925), 54; Elliot, 16.

${ }^{34}$ Elliot, 13.

${ }^{35}$ Francis Collinson, "Scottish Folkmusic: An Historical Survey," in Yearbook of the International Folk Music Council 3 (1971), 39.

${ }^{36}$ Elliot, 13.

${ }^{37}$ Ibid.

${ }^{38}$ Collinson, "Scottish Folkmusic," 39. 
looking at a possible connection between the vowel-rhythm relationship in waulking song refrains and the vowel-rhythm relationship in lilting.

Lilting may also be better understood if studied alongside other forms of "nonsense" music of other cultures, such as scat singing and Indian konnakol. There may be some similar characteristics, despite the varied cultural background.

Finally, further analysis may be made of the transcription of "Humours of Ballyloughlin." In particular, more attention may be given to the relationship of consonants to music, especially in regard to the onsets. It would be interesting to discover if any connection exists between metric or agogic accent and types of onsets, whether voiced, unvoiced, or absent.

\section{Conclusion}

Although lilting is improvisational and nonsensical, it is evident that it is hardly a random activity. Rather, the transcription and analysis of "Humours of Ballyloughlin" suggests that there are patterns within lilting that can help explain and distinguish this genre of music. Not only are the same (or similar) vocables repeated with frequency, but they also often appear in similar organizations throughout the work, as demonstrated most clearly by the parallelism between segments of repeated material. The attempt to relate vowels to relative pitch yielded uncertain evidence for a possible connection with Intrinsic Pitch, but a direct relationship between vocables and music is apparent in the often consistent relationship to metrical and agogic accents.

That said, there is yet much research to be done on the subject of lilting, and the extent to which the observations of Fay's "Humours of Ballyloughlin" may be true of the broader genre of lilting is therefore currently unknown. However, even if characteristics found within this example eventually prove not to be universally true of its genre, the present analysis still highlights some features that can certainly be included within the category of traditional lilting. For example, the analysis includes a compilation of viable lilting vocables with, in a sense, rough instructions for how they may be appropriately organized within music. In this respect, it has value not only for future comparisons and analyses, but also for present compositions. 
Appendix A: Pronunciation Key for Phonetic Symbols Used in Lilting Transcription $^{39}$

\begin{tabular}{|c|c|}
\hline & Examples \\
\hline [a] & pot, father, sergeant, honor, hospital \\
\hline [æ] & bat, laugh, anger, bang, comrade, rally, hand \\
\hline [aI] & I, bite, Stein, aisle, choir, island, fine \\
\hline [av] & bout, brown, doubt, flower, loud \\
\hline [d] & dip, card, drop, loved, batted \\
\hline [ə] & among, Asia, enough, famous, harmony \\
\hline [eI] & bait, reign, great, they, gauge, age \\
\hline [g] & guard, bag, finger, designate, Pittsburgh \\
\hline [h] & who, hat, rehash, hole, whole \\
\hline [i] & beat, we, believe, people, money, dean \\
\hline$[\mathrm{I}]$ & bit, consist, injury, malignant, gym, \\
\hline [j] & you, beautiful, feud, usse, yell \\
\hline [1] & leaf, feel, Lloyd, mild, applaud \\
\hline [m] & moose, lamb, smack, amnesty, ample \\
\hline [ov] & oh, boat, beau, grow, though, over \\
\hline [p] & pit, tip, spit, hiccough, appear \\
\hline$[\mathrm{I}]$ & reef, fear, Harris, prune, carp \\
\hline$[\mathrm{t}]$ & tag, pat, stick, pterodactyl, stuffed \\
\hline$[\mathrm{u}]$ & boot, who, sewer, duty, through, dune \\
\hline
\end{tabular}

* Apostrophes are used to denote breaths that seem to interfere with vocables.

${ }^{39}$ Mihalicek, 737. 
Appendix B: Transcription of "Humours of Ballyloughlin" 40
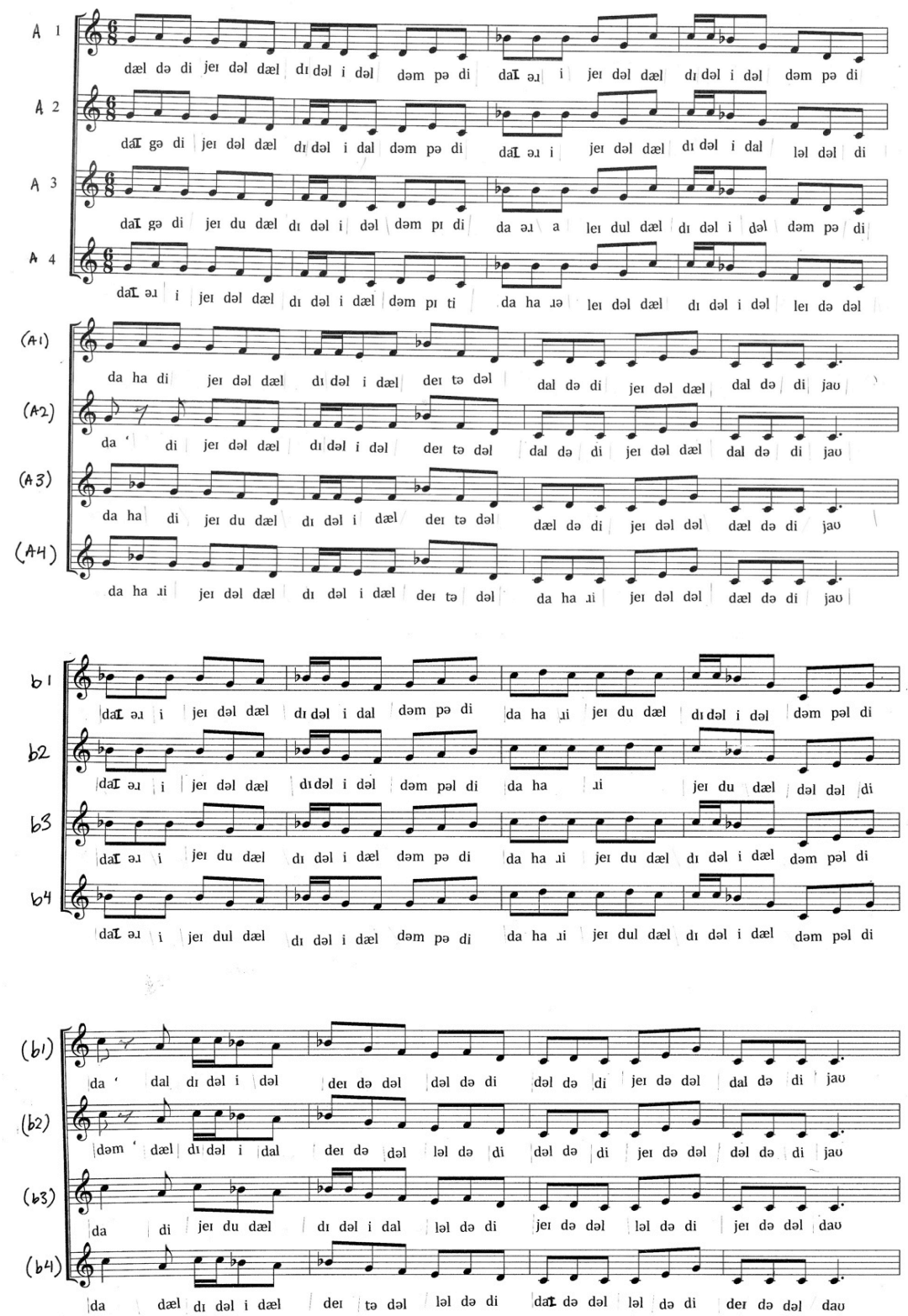

${ }^{40}$ Seamus Fay, Cavan's Lilter, sound recording, Dublin: Martin Donohoe NYAH, 2009. Transcription my own. 

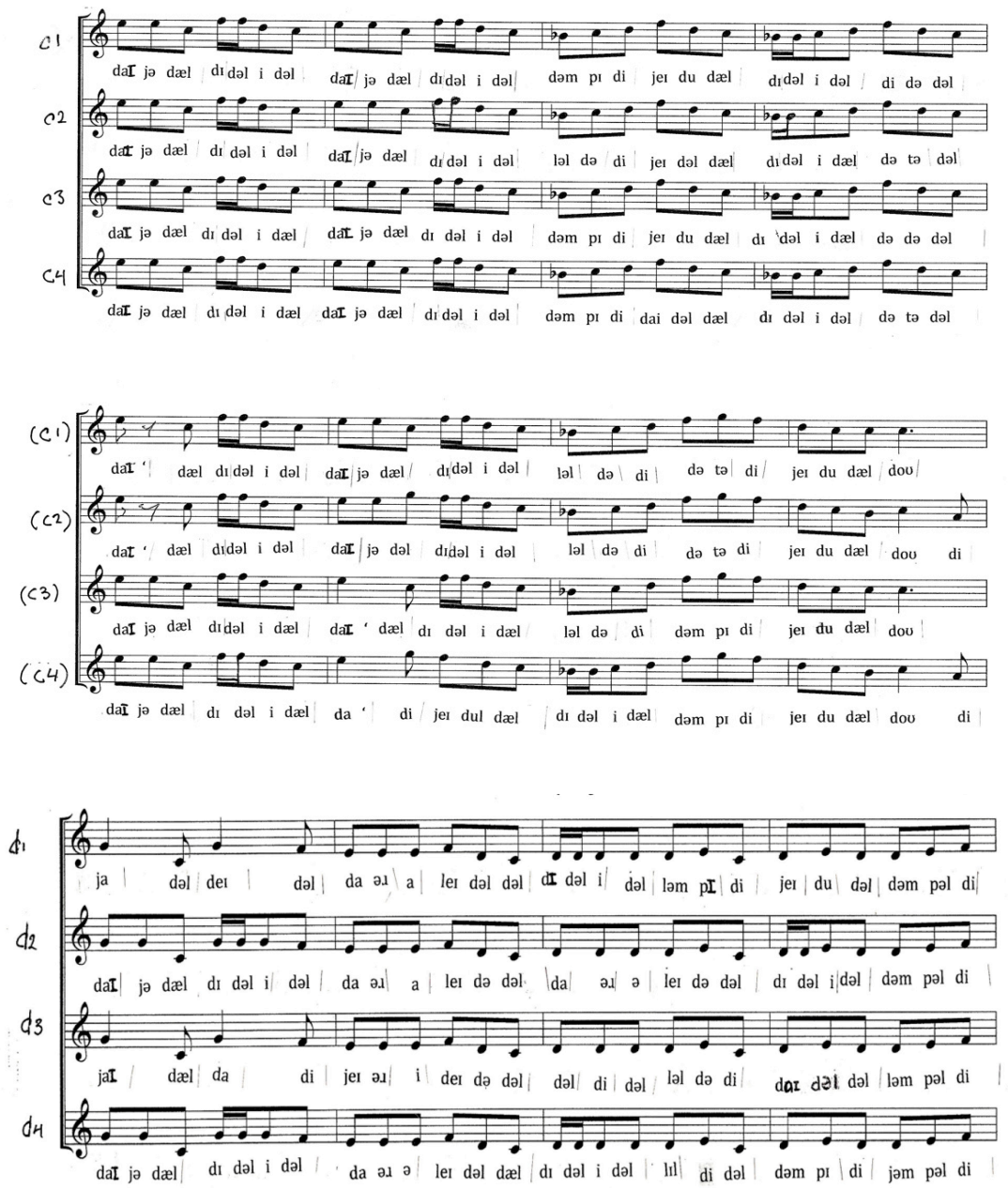

(di)

(d2)

(d3)

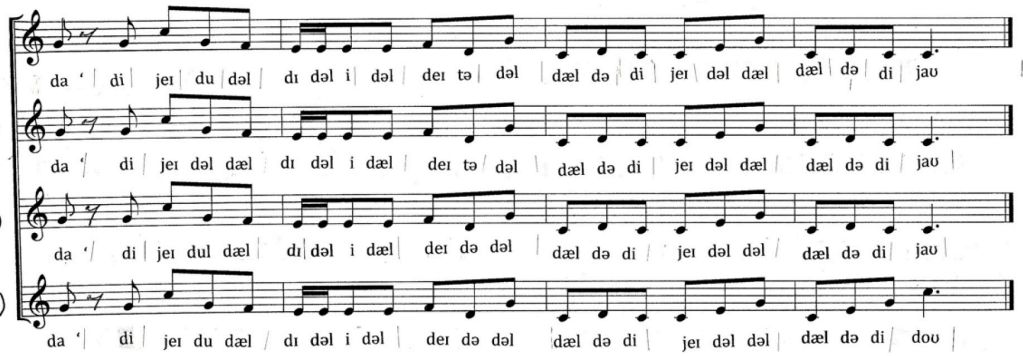


Appendix C: Observations Regarding Vocables ${ }^{41}$

\begin{tabular}{|c|c|}
\hline Vocable & Observations \\
\hline ja & Unusual-occurs once \\
\hline jai & $\begin{array}{l}\text { Unusual-occurs once; shows up in the same place in the } \\
\text { melody as [ja,] only in the repeated version }\end{array}$ \\
\hline daI & $\begin{array}{l}\text { Precedes [jə] and [ə.I] frequently; breath ('), [gə,] [dəl, } \\
\text { and [də] rarely }\end{array}$ \\
\hline da & $\begin{array}{l}\text { Precedes [ha] and [ə.] frequently, breath ('), [di,] and } \\
\text { [dæl] rarely }\end{array}$ \\
\hline dI & $\begin{array}{l}\text { Precedes [dəl] frequently and [də] rarely; generally short } \\
\text { duration }\left(16^{\text {th }} \text { note all but once }\right)\end{array}$ \\
\hline ləl & $\begin{array}{l}\text { Precedes [də] frequently and [dəl] rarely; always on beat, } \\
\text { but usually downbeat }\end{array}$ \\
\hline deI & Precedes [də] and [tə] frequently; [dəl] and [du] rarely \\
\hline dəm & $\begin{array}{l}\text { Always preceding [p], except in one instance where } \\
\text { singer takes breath; precedes [pə,] [pə,] and [pI] will } \\
\text { similar frequency }\end{array}$ \\
\hline jeI & Precedes [dəl] and [du] frequently; [də] and [du] rarely \\
\hline leI & $\begin{array}{l}\text { Usually preceded by [ə] or [a]; usually precedes [də] or } \\
{[\text { dəl] }}\end{array}$ \\
\hline jav & $\begin{array}{l}\text { Always at end of section of melody; preceded by [dal də } \\
\mathrm{di} \text {,] [dæl də di,] or [dəl də di;] always precedes [daI] }\end{array}$ \\
\hline dov & $\begin{array}{l}\text { Always at end of section of melody; usually preceded by } \\
\text { [jeI-du-dæl;] precedes [daI] or [di] }\end{array}$ \\
\hline dav & $\begin{array}{l}\text { Unusual; always at end of section of melody; preceded by } \\
\text { [jeI-də-dəl] or [deI-də-dəl;] always precedes [daI] }\end{array}$ \\
\hline ləm & $\begin{array}{l}\text { Unusual; possible variation of }[\mathrm{d} ə \mathrm{~m}] \text {; precedes vocable } \\
\text { starting with }[\mathrm{p}]\end{array}$ \\
\hline jəm & $\begin{array}{l}\text { Unusual; variation of }[\text { dəm]; precedes vocable starting } \\
\text { with }[\mathrm{p}]\end{array}$ \\
\hline lil & Unusual \\
\hline dal & $\begin{array}{l}\text { When occurring on the beat, precedes [də] frequently and } \\
\text { breath rarely; when occurring off the beat, preceded by [i]; } \\
\text { when occurring off the beat, always the last eighth note }\end{array}$ \\
\hline dæl & $\begin{array}{l}\text { Precedes and is preceded by variety of vocables; when } \\
\text { occurring off the beat, always the last eighth note }\end{array}$ \\
\hline
\end{tabular}

${ }^{41}$ In general, if the vocable lands on a beat, the only observation made is concerning which vocable it usually precedes. The vocables above are ordered according to their relative strength, as determined in Table 1. 


\begin{tabular}{|c|c|}
\hline si & $\begin{array}{l}\text { Always preceded by [ha]; always precedes [jer]; when } \\
\text { occurring off the beat, always the last eighth note; on the } \\
\text { one occasion this occurs on the beat, it is slurred such this } \\
\text { single vocable appear to cover } 3 \text { notes-very unusual, } \\
\text { difficult to transcribe }\end{array}$ \\
\hline də & $\begin{array}{l}\text { Preceded by variety of vocables; precedes vocables with } \\
\text { vowels [ə] and [I]; when occurring off the beat, never the } \\
\text { last eighth note }\end{array}$ \\
\hline dəl & $\begin{array}{l}\text { When preceded by [dI, always of short duration }\left(16^{\text {th }}\right. \\
\text { note) and followed be [i]; preceded by variety; may occur } \\
\text { in any position }\end{array}$ \\
\hline di & Always last eighth of a beat; sounds like pick-up note \\
\hline $\mathrm{i}$ & $\begin{array}{l}\text { Precedes [dəl,] [dal,] or [dæl]; when penultimate eighth } \\
\text { note within a beat, preceded by [dəl]; when ultimate } \\
\text { eighth note within a beat, preceded by [ə.I] }\end{array}$ \\
\hline $\mathrm{du}$ & $\begin{array}{l}\text { Always on penultimate eighth note within a beat; } \\
\text { preceded by [jeI]; precedes [dəl] once but [dæl] frequently }\end{array}$ \\
\hline jə & $\begin{array}{l}\text { Always on penultimate eighth note within first beat; } \\
\text { preceded by [dar]; highly fixed position in terms of both } \\
\text { vocables and meter }\end{array}$ \\
\hline วI & $\begin{array}{l}\text { Always on penultimate eighth note within first beat; } \\
\text { usually preceded by [daI] of [da]; usually precedes [i] }\end{array}$ \\
\hline to & $\begin{array}{l}\text { Always on penultimate eighth note within beat; hard to } \\
\text { distinguish from [də]; usually preceded by [deI]; usually } \\
\text { precedes [dəl] }\end{array}$ \\
\hline pəl & $\begin{array}{l}\text { Always on penultimate eighth within second beat of } \\
\text { measure; preceded with vocable involving [əm]; precedes } \\
\text { [di] }\end{array}$ \\
\hline ha & $\begin{array}{l}\text { Always on penultimate eighth note within first beat; } \\
\text { preceded by [da]; usually precedes [.ii] }\end{array}$ \\
\hline pI & $\begin{array}{l}\text { Always on penultimate eighth note within beat; usually } \\
\text { preceded by [dəm]; usually precedes [di] }\end{array}$ \\
\hline pə & $\begin{array}{l}\text { Always on penultimate eighth within second beat of } \\
\text { measure; preceded by [dəm]; precedes [di] }\end{array}$ \\
\hline dul & $\begin{array}{l}\text { Always on penultimate eighth within second beat of } \\
\text { measure; only appears in repeated version of melody; } \\
\text { usually preceded by [jəI]; precedes [dæl] }\end{array}$ \\
\hline $\mathrm{a}$ & $\begin{array}{l}\text { Always on last eighth of first beat of measure; preceded } \\
\text { by [ə.]; precedes [leI] }\end{array}$ \\
\hline
\end{tabular}




\begin{tabular}{|l|l|}
\hline$\curvearrowright$ & $\begin{array}{c}\text { Always on last eighth of first beat of measure; preceded } \\
\text { by [ə.]; precedes [leI] }\end{array}$ \\
\hline gə & $\begin{array}{l}\text { Unusual; always on penultimate eighth note within first } \\
\text { beat; preceded by [daI]; precedes [di] }\end{array}$ \\
\hline tə & Unusual-occurs once \\
\hline $\mathrm{ti}$ & Unusual-occurs once \\
\hline
\end{tabular}


Appendix D: Non-Lexical Vocable Groups ${ }^{42}$

\begin{tabular}{|c|c|c|c|}
\hline 1. & da-'-dal & 30. & dəm-pə-di \\
\hline 2. & da---dæl & 31. & dəm-pəl-di \\
\hline 3. & da---di & 32. & dəm-pI-di \\
\hline 4. & da-'-di & 33. & di-də-dəl \\
\hline 5. & da-əI-a & 34. & dI- dəl -i-dal \\
\hline 6. & da-วI-ə & 35. & dI- dəl -i-dæl \\
\hline 7. & da-ha-- & 36. & dI-dəl-i-dəl \\
\hline 8. & da-ha-di & 37. & dav \\
\hline 9. & da-ha-ıi & 38. & dov \\
\hline 10. & da-ha-ıə & 39. & dov---di \\
\hline 11. & dal-də-di & 40. & ja---dəl \\
\hline 12. & daI-'-dæl & 41. & jaI---dæl \\
\hline 13. & daI-də-dəl & 42. & jav \\
\hline 14. & daI-dəl-dəl & 43. & jeI-də-dəl \\
\hline 15. & daI-gə-di & 44. & jeI-dəl-dæl \\
\hline 16. & daI-əs-i & 45. & jeI-dəl-də1 \\
\hline 17. & daI-jə-dæl & 46. & jeI-du-dæl \\
\hline 18 & dæl-də-di & 47. & jeI-dul-dæl \\
\hline 19. & də-də-dəl & 48. & jeI-əI-i \\
\hline 20. & də-tə-dəl & 49. & jəm-pəl-di \\
\hline 21. & də-tə-di & 50. & leI-də-dəl \\
\hline 22. & deI-də-dəl & 51. & leI-dəl-dæl \\
\hline 23. & deI---dəl & 52. & leI-dəl-dəl \\
\hline 24. & deI-tə-də & 53. & ləl-də-di \\
\hline 25. & deI-tə-dəl & 54. & ləl-dəl-di \\
\hline 26. & dəl-də-di & 55. & ləm-pəl-di \\
\hline 27. & dəl-dəl-di & 56. & ləm-pi-di \\
\hline 28. & dəl-di-dəl & 57. & lil-di-dəl \\
\hline 29. & dəm-'-dæl & 58. & Ii \\
\hline
\end{tabular}

${ }^{42}$ A group includes all vocables that fall within a single beat. Dashes are used for convenience to distinguish vocables within a group. Three dashes between two vocables indicate that the first vocable is held twice as long as the second. Apostrophes denote a breath taken in a position that seemed to replace a vocable. 
Appendix E: Vowels and Melodic Motion

The numbers indicate how many times one of the vowels in the left column preceded one of the vowels in the top row. The symbols to the right of the numbers indicate the direction the pitch moved, whether up $(+)$, down $(-)$, or whether it remained the same $(=){ }^{43}$

\begin{tabular}{|c|c|c|c|c|c|c|c|c|c|c|}
\hline & $\mathrm{a}$ & aI & $\mathfrak{x}$ & av & $\partial$ & eI & i & I & ov & $\mathrm{u}$ \\
\hline $\mathrm{a}$ & $\begin{array}{l}8+ \\
1-\end{array}$ & & 1- & & $\begin{array}{l}4+ \\
9= \\
3-\end{array}$ & $\begin{array}{l}2+ \\
1=\end{array}$ & $\begin{array}{l}5= \\
11-\end{array}$ & $1+$ & & \\
\hline aI & & & 4- & & $\begin{array}{l}5+ \\
20= \\
1=\end{array}$ & & & & & \\
\hline æ & $\begin{array}{l}2+ \\
2-\end{array}$ & $3+$ & $2-$ & & $\begin{array}{l}16+ \\
2= \\
4-\end{array}$ & $6+$ & & 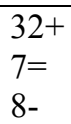 & $\begin{array}{l}2+ \\
2=\end{array}$ & \\
\hline $\mathrm{av}$ & & $11+$ & & & & & & & & \\
\hline$\partial$ & $\begin{array}{l}+ \\
3= \\
7-\end{array}$ & $\begin{array}{l}8+ \\
2-\end{array}$ & $\begin{array}{l}9+ \\
31-\end{array}$ & $2=$ & $\begin{array}{l}44+ \\
12= \\
40-\end{array}$ & $\begin{array}{l}6^{+} \\
2= \\
1-\end{array}$ & $\begin{array}{l}25+ \\
22= \\
66-\end{array}$ & $\begin{array}{l}12+ \\
1= \\
1-\end{array}$ & & \\
\hline eI & & & & & $\begin{array}{l}12+ \\
3= \\
30-\end{array}$ & & & & & $\begin{array}{l}4+ \\
17-\end{array}$ \\
\hline $\mathrm{i}$ & $\begin{array}{l}16+ \\
6-\end{array}$ & $\begin{array}{l}4+ \\
2-\end{array}$ & $\begin{array}{l}6+ \\
2= \\
11-\end{array}$ & $9=$ & $\begin{array}{l}7+ \\
5= \\
24-\end{array}$ & $\begin{array}{l}10+ \\
28= \\
9-\end{array}$ & & & $1+$ & \\
\hline I & & & & & $\begin{array}{l}52= \\
1-\end{array}$ & & $\begin{array}{l}4+ \\
6-\end{array}$ & & & \\
\hline ov & & $2+$ & & & & & $2-$ & & & \\
\hline $\mathrm{u}$ & & $\begin{array}{l}3+ \\
2= \\
14-\end{array}$ & & $2-$ & & & & & & \\
\hline Total & $\begin{array}{l}29+ \\
3= \\
16-\end{array}$ & $\begin{array}{l}31+ \\
2= \\
18-\end{array}$ & $\begin{array}{l}15+ \\
2= \\
49-\end{array}$ & $\begin{array}{l}11= \\
2-\end{array}$ & $\begin{array}{l}88+ \\
103= \\
103-\end{array}$ & $\begin{array}{l}24+ \\
31= \\
10-\end{array}$ & $\begin{array}{l}29+ \\
27= \\
85-\end{array}$ & $\begin{array}{l}45+ \\
8= \\
9-\end{array}$ & $\begin{array}{l}3+ \\
2=\end{array}$ & $\begin{array}{l}4+ \\
17-\end{array}$ \\
\hline
\end{tabular}

${ }^{43}$ This chart is based off a model found in Hughes, "Oral Mnemonics in Korean Music," 309. Breaths that seemed to interfere with vocables were ignored in the creation of this chart. 


\section{Bibliography}

Bartók, Béla and Albert Bates Lord. Serbo-Croatian Folk Songs: Texts and Transcriptions of Seventy-Five Folk Songs from the Milman Parry Collection and a Morphology of Serbo-Croatian Folk Melodies. New York: Columbia University Press, 1951.

Black, Jimmy. “1 Diddling.” Youtube video, 8:56. From a series for Radio Tay's Campus Magazine broadcast in the early 1990s. Posted by Jimmy Black, February 19, 2013. http://www.youtube.com/watch?v=0ydUfCGZ3Qo\&list=LLrx qd2wtfrMtYFLQNwDT6OQ.

Cannon, Roderick D. The Highland Bagpipe and Its Music. Edinburgh: John Donald, 1988.

Celtic Grooves. "Seamus Fay: Cavan's Lilter." Our Catalog. http://celticgrooves.homestead.com/CG_Fay_Seamus.html.

Chalmers, Kenneth. "Puirt-a-beul." In The Oxford Companion to Music.Oxford University Press, 2013. http://www.oxfordmusiconline.com/subscriber/article/opr/t114/ $\underline{\mathrm{e} 5409}$.

Collinson, Francis. "Scottish Folkmusic: An Historical Survey." Yearbook of the International Folk Music Council 3 (1971), 34-44, doi: 10.2307/767455.

Collinson, Francis and Peter Cooke. "Lilt." Grove Music Online. Oxford University Press, 2013.

Cooke, Peter. "Problems of Notating Pibroch: a study of 'Maol Donn.'" In The Highland Bagpipe: Music, History, Tradition. Edited by Joshua Dickson. Farnham and Burlington: Ashgate, 2009, 5-22.

Coolen, Michael. "2013 Indiana All State High School Honor Choir - An AfroCeltic Diddle." Youtube video, 3:17. Posted by “secvideo1," January 20, 2013.

http://www.youtube.com/watch? $\mathrm{v}=\mathrm{dW6ljKTACXM \& list=LLrxqd2wtf}$ rMtYFLQNwDT6OQ. 
De'Ath, Leslie. "Linguistic Lingo and Lyric Diction. I: The Phoneme." Journal of Singing: The Official Journal Of the National Association Of Teachers Of Singing 67, no. 2 (Nov/Dec 2010): 187-193, Education Research Complete, EBSCOhost.

."Linguistic Lingo and Lyric Diction. II: Syllabification." Journal of Singing: The Official Journal Of the National Association Of Teachers Of Singing 67, no. 4 (Mar/Apr 2011), 427-35, Education Research Complete, EBSCOhost.

"Linguistic Lingo and Lyric Diction. III: Pronunciation Contrasts." Journal of Singing: The Official Journal Of the National Association Of Teachers Of Singing 68, no. 2 (Nov/Dec 2011), 179-190, Education Research Complete, EBSCOhost.

"Linguistic Lingo and Lyric Diction. IV: Lexical Juncture in English." Journal of Singing: The Official Journal Of the National Association Of Teachers Of Singing 69, no. 2 (Nov/Dec 2012), 179-190, Education Research Complete, EBSCOhost.

"Linguistic Lingo and Lyric Diction. V: Phrasal Juncture." Journal of Singing: The Official Journal Of the National Association Of Teachers Of Singing 69, no. 5 (May/June 2013), 577-588, Education Research Complete, EBSCOhost.

"Linguistic Challenges in the Voice Studio." Journal of Singing: The Official Journal Of the National Association Of Teachers Of Singing 63, no. 2 (Nov/Dec 2006), 189-200, Education Research Complete, EBSCOhost.

"Phonemics and Lyric Diction." Journal of Singing: The Official Journal Of the National Association Of Teachers Of Singing 62, no.5 (May/June 2006), 549-61, Education Research Complete, EBSCOhost.

Elliott, Kenneth, et al. "Scotland." In Grove Music Online. Oxford University Press, 2013. http://www.oxfordmusiconline.com/subscriber/article/grove/m usic/40113. 
Fay, Séamus. Cavan's Lilter. Sound Recording, Dublin: Martin Donohoe NYAH, 2009.

- "Seamus Fay at Echoes of Erin, 2011." Youtube video, 2:26. From a performance at the "Echoes of Erin" tour in London, 2011. Posted by James McDonald, June 2, 2011. http://www.youtube.com/watch? $\mathrm{v}=$ bmfaQbg2COc\&list=LLrxq d2wtfrMtYFLQNwDT6OQ.

. "Spirit of Voice SEAMUS FAY." Youtube video, 2:38. From a performance at the "Spirit of Voice Festival," November 10, 2007. Posted by "spirit of voice festival," August 7, 2009. http://www.youtube.com/watch? $\mathrm{v}=\mathrm{gU} 12 \mathrm{Ur}-$ b6jc\&list=LLrxqd2wtfrMtYFLQNwDT6OQ.

- "Lilter Seamus Fay in Cavan." Youtube video, 2:47. Posted by "Nyah Cavan," November 20, 2007.

http://www.youtube.com/watch?v=vhxfcJCeIWQ\&list=LLrxq d2wtfrMtYFLQNwDT6OQ.

. "Séamus Faye - Portaireacht bhéil, Lilting, mouth music, Geantraí." Youtube video, 13:22. Posted by “TG Amhrán," December 12, 2012. http://www.youtube.com/watch?v=IQhoC36Dohs\&list=LLrxqd2wtfrM tYFLQNwDT6OQ.

Fay, Seamus, and Trevor Bury. "Seamus Fay." Youtube video, 1:47. From a session performance on December 29, 2010. Posted by "kavanmusicproduction." January 1, 2011. http://www.youtube.com/watch? $\mathrm{v}=$ FzBLd 4q1hE\&list=LLrxq d2wtfrMtYFLQNwDT6OQ.

Fay, Seamus, and Guido Plueschke. "Cavan Session lilting Seamus Fay and Guido Plueschke." Youtube video, 2:24. Posted by "BodhranWorld," July 19, 2012. http://www.youtube.com/watch?v=lrHhDmPp2Zk\&list=LLrxqd2wtfr MtYFLQNwDT6OQ.

Gibson, John G. Traditional Gaelic Bagpiping, 1745-1945. Montreal: McGill-Queen's University Press, 1998. 
Giddens, Rhiannon and Adam Matta. "Carolina Chocolate Drops LIVE "Mouth Music" (Featuring Adam Matta)." Youtube video, 3:34. From a performance at the Sunstar Music Festival. Posted by "The Hyper Channel," April 5, 2011. http://www.youtube.com/watch? $\mathrm{v}=\mathrm{iqRihplG} \mathrm{h0 \& list=LLrxqd2}$ wtfrMtYFLQNwDT6OQ\&feature $=$ mh lolz.

Grant, J. P. 1925. "Canntaireachd: the Old Pipers' Notation for Pibroch Music." Music and Letters 6, no. 1 (1925), 54-63, http://www.jstor.org/stable/726614.

Herzog, Avigdor. "Transcription and Transnotation in Ethnomusicology." In Journal of the International Folk Music Council 16 (1964), 100-101, doi:10.2307/835093.

Hughs, David W. "No Nonsense: The Logic and Power of AcousticIconic Mnemonic Systems." British Journal of Ethnomusicology 9, no. 2 (2000), 93-120, doi: $10.1080 / 09681220008567302$.

. "Oral Mnemonics in Korean Music: Data, Interpretation, and a Musicological Application." Bulletin of the School of Oriental and African Studies, University of London 54, no. 2 (1991), 307-335, doi:10.1017/S0041977X00014816.

. "The Historical Uses of Nonsense; Vowel-Pitch Solfège from Scotland to Japan." Ethnomusicology and the Historical Dimension; Papers Presented at the European Seminar in Ethnomusicology, London (1986), 3-18.

Kennedy-Fraser, Marjory. "Songs of the Hebrides." Proceedings of the Musical Association, 45 ${ }^{\text {th }}$ Sess. (1918-1919), 1-12.

Lillvik, Johanna. "Johanna Lillvik Diddling.” Youtube video, 1:27. Posted by "Joanna Lillvik," September 17, 2012. http://www.youtube.com/watch? $\mathrm{v}=\mathrm{uCYVaLUXK9s \& list=LLrx}$ qd2wtfrMtYFLQNwDT6OQ.

List, George. "The Musical Significance of Transcription: (Comments on Hood, 'Musical Significance').” Ethnomusicology 7, no. 3 (Sep., 1963), 193-197, doi:10.2307/924577. 
Maassarani Yasmin. "Cavan Lilter, Seamus Fay's Birthday Concert." Cavan Living. December 19, 2012.

http://www.cavanliving.ie/index.php/2012/12/19/lilter-seamusfays-birthday-concert-cavan/.

McFerrin, Bobby and Kieran Munnelly. "Bobby McFerrin \& Kieran Munnelly by John McCartin.” Youtube video, 3:29. Posted by "John McCartin," May 28, 2008. http://www.youtube.com/watch?v=jko9yvVoAsk\&list=LLrxqd 2wtfrMtYFLQNwDT6OQ.

Meyer, Moe. "Dance and the Politics of Orality: A Study of the Irish "Scoil Rince." Dance Research Journal 27, no. 1 (1995), 2539, doi: $10.2307 / 1478428$.

Mihalicek, Vedrana, and Christin Wilson. Language Files: Materials for an Introduction to Language and Linguistics. Columbus: Ohio State University Press, 2011.

Milligan, Jean. "Scottish Country Dancing." Journal or the International Folk Music Council 2 (1950), 32, doi:10.2307/835694.

O'Byrne, Fergus, and Jim Payne. "Newfoundland and Labrador Lilting." Youtube video, 1:03. From a performance at Newfoundland \& Labrador Tourism's TV launch. Posted by "Amy Fisher," January 21, 2013. http://www.youtube.com/watch?v=m7ZbuifdF8\&list=LLrxqd2wtfrMtYFLQNwDT6OQ.

Pinter, Istvan. "Computer Aided Transcription of Folk Music." Studia Musicologica Academiae Scientiarum Hungaricare, T. 40, 1, no. 3 (1999), 189-209, doi:10.2307/902558.

Porter, James. "Problems and Experiments in the Notational Method of Vocal Transcription." Scottish Studies, 1968, 169-178, RILM Abstracts of Music Literature, EBSCOhost. 
Sparling, Heather. "Puirt-a-beul: An Ethnographic Study of MouthMusic in Cape Breton." M.A. Thesis, York University in Toronto, Ontario, 1999, http://www.collectionscanada.gc.ca/obj/s4/f2/dsk2/ftp03/MQ56 204.pdf.

—_." "Music is Language and Language is Music': Language Attitudes and Musical Choices in Cape Breton, Nova Scotia." Ethnologies 25, no. 2 (2003), 145-171.

—. "Categorically Speaking: Towards a Theory of (Musical) Genre in Cape Breton Gaelic Culture." Ethnomusicology 52, no. 3 (2008), 410-425, http://www.jstor.org/stable/20174606.

Tanner, Phil. "Phil Tanner, 87, Diddles The Gower Reel And Sings The Wassail Song. 1947." Youtube video, 3:56. Posted by “Edmund StAustell," January 18, 2011. http://www.youtube.com/watch? $\mathrm{v}=\mathrm{T}-$ Clnc9KXSw\&list=LLrxqd2wtfrMtYFLQNwDT6OQ.

White, Harry and Nicholas Carolan. "Ireland." In Grove Music Online. Oxford University Press, 2013. http://www.oxfordmusiconline.com/subscriber/article/grove/m usic/13901. 